BEST EVIDENCE TOPIC REPORTS

\title{
Towards evidence based emergency medicine: best BETs from the Manchester Royal Infirmary
}

\author{
Edited by K Mackway-Jones
}

Emerg Med J 2003;20:61-67

Best evidence topic reports (BETs) summarise the evidence pertaining to particular clinical questions. They are not systematic reviews, but rather contain the best (highest level) evidence that can be practically obtained by busy practicing clinicians. The search strategies used to find the best evidence are reported in detail in order to allow clinicians to update searches whenever necessary. The BETs published below were first reported at the Critical Appraisal Journal Club at the Manchester Royal Infirmary' or placed on the BestBETs web site. Each BET has been constructed in the four stages that have been described elsewhere. ${ }^{2}$ The BETs shown here together with those published previously and those currently under construction can be seen at http://www. bestbets.org ${ }^{3}$ Eight BETs are included in this issue of the journal.

- Reduction of pulled elbows

- Alternative treatments for neck sprain

- Tetanus prophylaxis in supeficial corneal abrasions

- Gastric lavage in tricyclic antidepressant overdose

- Treatment of uncomplicated subungual haematoma

- Use of sterile gloves in the treatment of simple wounds

- Antibiotics in orbital floor fractures

- Contraindications to thrombolysis in patients on coumarins K Mackway Jones, Department of Emergency Medicine, Manchester Royal Infirmary, Oxford Road, Manchester M13 9WL, UK; kevin.mackway-jones@man.ac.uk

1 Carley SD, Mackway-Jones K, Jones A, et al. Moving towards evidence-based emergency medicine: use of a structured critical appraisal journal club. J Accid Emerg Med 1998;15:220-2.

2 Mackway-Jones K, Carley SD, Morton RJ, et al. The best evidence topic report: a modified CAT for summarising the available evidence in emergency medicine. J Accid Emerg Med 1998;15:222-6.

3 Mackway-Jones K, Carley SD. bestbets.org: Odds on favourite for evidence in emergency medicine reaches the worldwide web. J Accid Emerg Med 2000;17:235-6.

\section{Reduction of pulled elbows}

\section{Report by David Lewis, East Anglian Trainees Checked by Jon Argall, Senior Clinical Fellow Abstract}

A short cut review was carried out to establish whether a pronation manoeuvre is better than a supination manoeuvre for first time reduction of pulled elbow. Altogether 57 papers were found using the reported search, of which two presented the best evidence to answer the clinical question. The author, date and country of publication, patient group studied, study type, relevant outcomes, results and study weaknesses of these best papers are tabulated. A clinical bottom line is stated.

\section{Clinical scenario}

A 2 year old child is brought into the emergency department by her parents. They tell you that she has not used her left arm since tripping over while holding her older sister's hand. The child is holding her left arm flexed at the elbow and semi-prone. The diagnosis is clearly a pulled elbow. You have heard various colleagues arguing vehemently for pronation and supination manoeuvres, and wonder which is actually the best method for reduction?

\section{Three part question}

In [a patient with a pulled elbow] is [a pronation manoeuvre better than a supination manoeuvre] at achieving [reduction and return to function at the first attempt]?

\section{Search strategy}

Medline 1966-10/02 using the OVID interface. [exp Elbow OR exp Elbow joint OR elbow.mp] AND [exp adolescence OR exp child OR exp child of impaired parents OR exp child, abandoned OR exp child, exceptional OR exp child, hospitalized OR exp child, institutionalized OR exp child, preschool OR exp child, unwanted OR exp disabled children OR exp homeless youth OR exp infant OR exp only child OR child\$.mp Or exp Pediatrics OR pediatric\$.mp OR paediatric\$.mp] AND [exp Dislocations OR dislocation.mp OR subluxation.mp] AND [exp Manipulation, orthopedic OR manipulation.mp OR exp Pronation OR pronation.mp OR exp Supination OR supination.mp] LIMIT to human AND English.

\begin{tabular}{|c|c|c|c|c|c|}
\hline Author, date and country & Patient group & $\begin{array}{l}\text { Study type } \\
\text { (level of } \\
\text { evidence) }\end{array}$ & Outcomes & Key results & $\begin{array}{l}\text { Study } \\
\text { weaknesses }\end{array}$ \\
\hline Macias CG et al, 1998, USA & $\begin{array}{l}90 \text { patients with pulled elbow over } 12 \text { months } \\
\text { Pronation v supination }\end{array}$ & PRCT & Success rate & $95 \%$ v $77 \%$ & Not blinded \\
\hline McDonald J et al, 1999, USA & $\begin{array}{l}148 \text { patients with pulled elbow over } 16 \text { months } \\
\text { Pronation } v \text { supination }\end{array}$ & PRCT & $\begin{array}{l}\text { Success rate } \\
\text { Left arm only } \\
\text { Pain }\end{array}$ & $\begin{array}{l}80 \% \vee 69 \% \text { (NS) } \\
89 \% \vee 71 \% \\
\text { less with pronation (NS) }\end{array}$ & Not blinded \\
\hline
\end{tabular}




\section{Search outcome}

Altogether 57 papers were found of which 54 were irrelevant or of insufficient quality. The remaining three were all randomised controlled trials. One of these was looking at supination with flexion compared with extension. The remaining two papers are shown in table 1 .

\section{Comment(s)}

The classic method for reduction of pulled elbows is supination at the wrist followed by flexion at the elbow. There has been no difference demonstrated between flexion and extension during this manoeuvre. When studying a practical procedure it is impossible to exclude all bias and this may weaken these results.

\section{- CLINICAL BOTTOM LINE}

Pronation with or without elbow flexion is the first line method of reduction for pulled elbows.

Macias CG, Bothner J, Wiebe R. A comparison of supination/flexion to hyperpronation in reduction of radial head subluxations. Pediatrics 1998; 102:e10

McDonald J, Whitelaw C, Goldsmith LJ. Radial head subluxation: comparing two methods of reduction. Acad Emerg Med 1999;6:15-18.

\section{Alternative treatments for neck sprain}

\section{Report by Kerstin Hogg, Clinical Research Fellow \\ Checked by Rosemary Morton, Consultant Abstract}

A short cut review was carried out to establish whether osteopathy or chiropractic treatments improve outcome in patients with neck sprain. Altogether 206 papers were found using the reported search, of which nine presented the best evidence to answer the clinical question. The author, date and country of publication, patient group studied, study type, relevant outcomes, results and study weaknesses of these best papers are tabulated. A clinical bottom line is stated

\section{Clinical scenario}

A 25 year old woman attends the emergency department having been in a rear end shunt. She complains of pain in her neck. On examination she has right sternomastoid tenderness and restricted movement. You diagnose a neck sprain and advise physiotherapy, exercise and anti-inflammatory drugs. She asks you whether she should go and see an osteopath or a chiropractor. You wonder whether there is any evidence for these alternative treatments.

\section{Three part question}

In [adults with neck sprain] does [osteopathy or chiropractic] improve [outcome]?

\section{Search strategy}

Medline using the OVID interface 1966-10/02, Cochrane Library 2002 Issue 3 and hand search of paper references. [(exp Neck injuries OR exp Neck pain OR neck.mp OR whiplash.mp) AND (exp Osteopathic medicine OR osteopath\$.mp OR chirop\$.mp)] LIMIT to human AND English.

\section{Search outcome}

Altogether 206 papers were found, of which 13 were relevant. One literature review is not included in table 2 as all the papers are either represented in another review or described separately. Three papers were excluded on the basis of having 10 or fewer patients. The remaining nine papers are shown in table 2 .
Many of the studies also include patients with lower back pain-only the neck pain patients are described in table 2 .

\section{Comments}

Virtually all of these studies are flawed and the numbers tiny. In particular there are no powerful studies comparing best conventional treatment with best alternative treatments. There were no papers relating directly to osteopathy.

\section{- CLINICAL BOTTOM LINE}

Chiropractic therapy is associated with improvement in neck symptoms but there is no evidence to show whether this improvement is greater or worse than that obtained with conventional treatment.

Koes BW, Assendlft WJJ, van der Heijden GJMG, et al. Spinal manipulation and mobilisation for back and neck pain: a blinded review. BM

1991;303:1298-303.

Cassidy JD, Lopes AA, Yong-Hing K. The immediate effect of manipulation versus mobilisation on pain and range of motion in the cervical spine: a randomised controlled trial. J Manipulative Physiol Ther 1992;15:570-5.

Koes BW, Bouter LM, van Mameren $\mathrm{H}$, et al. A randomised clinical trial of manual therapy and physiotherapy for persistent back and neck complaints: subgroup analysis and relationship between outcome measures. J Manipulative Physiol Ther 1993;16:211-19.

Skargren EI, Oberg BE, Carlsson PG, et al. Cost effectiveness analysis of chiropractic and physiotherapy treatment for low back and neck pain. Spine 1998:22:2167-77.

Verhoef MJ, Page SA, Waddell SC. The chiropractic outcome study: pain, functional ability and Satisfaction with care. J Manipulative Physiol Ther 1997;20:235-40

Woodward MN, Cook JCH, Gargan MF, et al. Chiropractic treatment of chronic whiplash injuries. Injury 1996;27:643-5.

Jordan A, Bendrix $T$, Nielsen $\mathrm{H}$, et al. Intensive training, physiotherapy, or manipulation for patients with chronic neck pain. Spine 1998;23:311-19.

Giles LGF, Muller R. Chronic spinal pain syndromes: a clinical pilot trial comparing acupuncture, a non-steroidal anti-inflammatory drug and spinal manipulation. J Manipulative Physiol Ther 1999;22:376-81

McMorland G. Suter E. Chiropractic management of mechanical neck and low-back pain: a retrospective, outcome-based analysis. J Manipulative Physiol Ther 1999;23:307-11

\section{Tetanus prophylaxis in superficial corneal abrasions}

\section{Report by Prodeep Mukheriee, Specialist Registrar Checked by A Sivakumar, Consultant Abstract}

A short cut review was carried out to establish whether tetanus prophylaxis is indicated after non-penetrating corneal abrasion. Altogether 30 papers were found using the reported search, of which one presented the best evidence to answer the clinical question. The author, date and country of publication, patient group studied, study type, relevant outcomes, results and study weaknesses of this best paper are tabulated. A clinical bottom line is stated.

\section{Clinical scenario}

A 44 year old man presents to the emergency department with a foreign body sensation in his right eye. Fluorescein examination reveals a piece of grit. After removal there is a small corneal abrasion with no evidence of perforation. The patient has had a primary course of tetanus antitoxin and thinks his only tetanus booster was less than 10 years ago but is not sure. You wonder whether the patient requires a tetanus booster to reduce any risk from the abrasion.

\section{Three part question}

In [patients with non penetrating corneal abrasion] is [tetanus toxoid booster] necessary to [prevent clinical tetanus infection]? 


\section{Search strategy}

Medline 1966-10/02 using the OVID interface. [(exp tetanus OR exp tetanus antitoxin OR exp tetanus toxin OR exp tetanus toxoid OR tetanus.mp) AND (exp Cornea OR corneal abrasion.mp OR exp Eye Injuries OR exp Eye Foreign Bodies OR exp Wounds, Nonpenetrating)].

\section{Search outcome}

Altogether 31 papers found of which 21 were irrelevant or of insufficient quality for inclusion. Five papers on cases of teta- nus following penetrating eye injuries, one paper on tetanus from an eyelid injury, and three papers on treatment of ocular animal bite injuries were excluded as not directly relevant. The remaining paper is shown in table 3.

\section{Comment(s)}

The only relevant paper found was an experimental animal study. Unlike skin, corneal epithelium does not have an underlying blood supply (receiving nutrients from the aqueous humor) and often shows substantial healing within six hours of

\section{Table 2}

\begin{tabular}{|c|c|c|c|c|c|}
\hline $\begin{array}{l}\text { Author, date } \\
\text { and country }\end{array}$ & Patient group & $\begin{array}{l}\text { Study type } \\
\text { (level of } \\
\text { evidence) }\end{array}$ & Outcomes & Key results & Study weaknesses \\
\hline $\begin{array}{l}\text { Koes BW et al, } \\
\text { Netherlands, } \\
1991\end{array}$ & $\begin{array}{l}5 \text { RCTs all comparing } \\
\text { cervical manipulation to } \\
\text { a control } \\
\text { Total number of patients } \\
\text { combined } 111\end{array}$ & Review & Recovery & $\begin{array}{l}3 \text { studies concluded manipulation } \\
\text { better than collar and analgesics. } \\
2 \text { studies showed no significant } \\
\text { difference between manipulation } \\
\text { and diazepam, a collar and } \\
\text { transcutaneous nerve stimulation }\end{array}$ & $\begin{array}{l}\text { Studies rated poor-moderate } \\
\text { on methodology scoring }\end{array}$ \\
\hline $\begin{array}{l}\text { Cassidy JD et al, } \\
\text { Canada, } 1992\end{array}$ & $\begin{array}{l}100 \text { patients with } \\
\text { mechanical neck pain, } \\
\text { One manipulation } v \\
\text { mobilization }\end{array}$ & RCT & $\begin{array}{l}\text { Mean improvement in } \\
\text { pain as measured by } \\
\text { visual analogue scale }\end{array}$ & 17.3 (SD19.5) v 10.5 (SD 14.8) & $\begin{array}{l}\text { Only one treatment with pain } \\
\text { score repeated immediately } \\
\text { afterwards } \\
\text { No long term follow up } \\
\text { Manipulation was not carried } \\
\text { out by an osteopath or } \\
\text { chiropractor }\end{array}$ \\
\hline $\begin{array}{l}\text { Koes BW et al, } \\
\text { Netherlands, } \\
1993\end{array}$ & $\begin{array}{l}29 \text { patient with neck } \\
\text { pain } \\
\text { physiotherapy }(n=17) \mathrm{v} \\
\text { manual therapy } n=12 \\
\text { (manipulation and } \\
\text { mobilisation) }\end{array}$ & RCT & $\begin{array}{l}\text { Subjective pain } \\
\text { measurement and } \\
\text { physical function over } 12 \\
\text { months }\end{array}$ & $\begin{array}{l}\text { Both groups improved without any } \\
\text { statistical difference between groups }\end{array}$ & $\begin{array}{l}\text { Patients were also assigned } \\
\text { to receive treatment by their } \\
\text { GP and placebo. These } \\
\text { results were not reported } \\
\text { Small numbers }\end{array}$ \\
\hline $\begin{array}{l}\text { Skargren El et } \\
\text { al, Sweden, } \\
1996\end{array}$ & $\begin{array}{l}70 \text { patients with neck } \\
\text { pain } \\
\text { physiotherapy }(n=29) v \\
\text { chiropractic }(n=41)\end{array}$ & RCT & $\begin{array}{l}\text { Subjective pain; Function, } \\
\text { general health } \\
\text { Sick leave } \\
\text { Fulfillment of patient } \\
\text { expectation. } \\
\text { All measured until } 6 \\
\text { months }\end{array}$ & $\begin{array}{l}\text { Significant improvement in pain, } \\
\text { function and general health in both } \\
\text { groups } \\
\text { No difference } \\
41 \% \text { of chiropractic group v } 24 \% \\
\text { physiotherapy group }\end{array}$ & $\begin{array}{l}\text { No breakdown of results } \\
\text { between back and neck pain } \\
\text { patients given for the last } 2 \\
\text { outcomes }\end{array}$ \\
\hline $\begin{array}{l}\text { Verhoef } M \text { et } \\
\text { al, Canada, } \\
1997\end{array}$ & $\begin{array}{l}106 \text { patients with neck } \\
\text { pain and } 88 \text { with neck } \\
\text { and back pain. } \\
\text { All had chiropractic } \\
\text { manipulation }\end{array}$ & $\begin{array}{l}\text { Prospective } \\
\text { cohort }\end{array}$ & $\begin{array}{l}\text { Disability (Neck Disability } \\
\text { Index) }\end{array}$ & $\begin{array}{l}\text { Baseline mean score } 23.5 \text {, mean } \\
\text { score at } 6 \text { weeks } 13.3 p<0.001\end{array}$ & No control group \\
\hline $\begin{array}{l}\text { Woodward MN } \\
\text { et al, UK, } 1996\end{array}$ & $\begin{array}{l}28 \text { patients with chronic } \\
\text { "whiplash" syndrome. } \\
\text { All had chiropractic } \\
\text { manipulation }\end{array}$ & $\begin{array}{l}\text { Retrospective } \\
\text { cohort }\end{array}$ & $\begin{array}{l}\text { Disability at baseline and } \\
\text { following treatment }\end{array}$ & $\begin{array}{l}26 / 28 \text { patients had reduction in } \\
\text { disability }\end{array}$ & $\begin{array}{l}\text { Follow-up time period not } \\
\text { specified } \\
\text { Disability classified by either } \\
\text { a chiropractor or by an } \\
\text { orthopaedic doctor over the } \\
\text { phone } \\
\text { No control group }\end{array}$ \\
\hline $\begin{array}{l}\text { Jordan A et al, } \\
\text { Denmark, } 1998\end{array}$ & $\begin{array}{l}119 \text { patients with neck } \\
\text { pain for more than } 3 \\
\text { months } \\
\text { intensive training } \\
\text { physiotherapy } v \\
\text { chiropractic treatment }\end{array}$ & RCT & $\begin{array}{l}\text { Self reported pain and } \\
\text { disability } \\
\text { Medication use } \\
\text { All of above measured } \\
\text { until } 12 \text { months. }\end{array}$ & $\begin{array}{l}\text { All treatment modality groups had } \\
\text { improved pain levels and disability } \\
\text { scores } \\
\text { All groups progressively reduced } \\
\text { analgesic intake }\end{array}$ & $\begin{array}{l}\text { All groups underwent } \\
\text { intervention. } \\
\text { No comparison with natural } \\
\text { progression of injury }\end{array}$ \\
\hline $\begin{array}{l}\text { Giles LGF and } \\
\text { Muller R, } \\
\text { Australia, } 1999\end{array}$ & $\begin{array}{l}33 \text { patients with neck } \\
\text { pain for at least } 13 \\
\text { weeks, } \\
\text { chiropractor } \\
\text { manipulation }(n=18) \text {, } \\
\text { acupuncture }(n=7) \text { or } \\
\text { medication }(n=7)\end{array}$ & RCT & $\begin{array}{l}\text { Disability (Neck Disability } \\
\text { Index) Measured at } 4 \\
\text { weeks } \\
\text { Pain as measured by } \\
\text { visual analogue scale }\end{array}$ & $\begin{array}{l}\text { Manipulation group median index } \\
\text { score reduced by } 10 \text { points } \\
p=0.001 \\
\text { No statistically significant reduction } \\
\text { in acupuncture or medication group } \\
\text { Manipulation group median pain } \\
\text { score reduced by } 1.5 \text { points } \\
p=0.002 \\
\text { No statistically significant reduction } \\
\text { in acupuncture or medication groups }\end{array}$ & $\begin{array}{l}\text { Very small numbers } \\
\text { particularly in acupuncture } \\
\text { and medication groups } \\
\text { Numbers within table } \\
\text { referring to number of patient } \\
\text { with neck pain do not add up }\end{array}$ \\
\hline $\begin{array}{l}\text { McMorland G } \\
\text { and Suter E, } \\
\text { Canada, } 1999\end{array}$ & $\begin{array}{l}61 \text { patients presenting to } \\
\text { chiropractic with neck } \\
\text { pain. All received } \\
\text { chiropractic manipulation }\end{array}$ & $\begin{array}{l}\text { Retrospective } \\
\text { cohort }\end{array}$ & $\begin{array}{l}\text { Neck Disability Index } \\
\text { score }\end{array}$ & $\begin{array}{l}\text { Reduction in score after } 4 \text { weeks of } \\
\text { treatment }\end{array}$ & $\begin{array}{l}\text { No statistics displayed } \\
244 \text { patients who did not } \\
\text { complete therapy because } \\
\text { they got better or worse were } \\
\text { excluded! } \\
\text { No control group }\end{array}$ \\
\hline
\end{tabular}




\begin{tabular}{|c|c|c|c|c|c|}
\hline $\begin{array}{l}\text { Author, date and } \\
\text { country }\end{array}$ & Patient group & $\begin{array}{l}\text { Study type (level of } \\
\text { evidence) }\end{array}$ & Outcomes & Key results & Study weaknesses \\
\hline \multirow{2}{*}{$\begin{array}{l}\text { Benson WH et al, } \\
\text { 1993, USA }\end{array}$} & Unimmunised mice & \multirow{2}{*}{$\begin{array}{l}\text { (Prospective) } \\
\text { Experimental animal } \\
\text { model }\end{array}$} & \multirow[b]{2}{*}{$\begin{array}{l}\text { Incidence of clinical tetanus } \\
\text { following: } \\
\text { - corneal abrasion } \\
\text { - corneal penetration } \\
\text { - corneal perforation } \\
\text { Incidence in immunised mice }\end{array}$} & & Animal model \\
\hline & $\begin{array}{l}\text { Animal model surgically } \\
\text { injecting live } C \text { tetani or } \\
\text { tetanus toxin into mice } \\
\text { cornea }\end{array}$ & & & $\begin{array}{l}0 / 9 \\
0 / 9 \\
10 / 27 \\
0 / 42\end{array}$ & $\begin{array}{l}\text { C tetani organisms and toxin } \\
\text { used pure - not representative } \\
\text { of usual clinical mixed flora }\end{array}$ \\
\hline
\end{tabular}

injury. Criteria for deciding if a corneal abrasion is tetanus prone or not should therefore probably be different than that for standard skin abrasions. Finally there are no case reports in the literature of clinical tetanus developing from a simple corneal abrasion. In clinical practice it should be remembered that there may be public health benefits in encouraging tetanus prophylaxis whenever the opportunity arises.

\section{- CLINICAL BOTTOM LINE}

There is no clinical reason to provide tetanus prophylaxis in the emergency department following superficial corneal abrasions with no evidence of perforation, infection, or devitalised tissue.

Benson WH, Snyder IS, Granus V, et al. Tetanus prophylaxis following ocular injuries. J Emerg Med 1993;11:677-83.

\section{Gastric lavage in tricyclic antidepressant overdose}

\section{Report by Stewart Teece, Clinical Research Fellow \\ Checked by Kirsten Hogg, Clinical Research \\ Fellow}

\section{Abstract}

A short cut review was carried out to establish whether gastric lavage is indicated after tricyclic antidepressant overdose. Altogether 82 papers were found using the reported search, of which one presented the best evidence to answer the clinical question. The author, date and country of publication, patient group studied, study type, relevant outcomes, results and study weaknesses of this best paper are tabulated. A clinical bottom line is stated.

\section{Clinical scenario}

A 23 year old air hostess is brought into the emergency department having been found collapsed next to an empty bottle of amitriptyline. She has a Glasgow Coma Scale score of 7/15, is tachycardic and twitchy. After a rapid sequence induction and intubation you wonder whether there is any benefit from gastric lavage.

\section{Three part question}

[In overdose of tricyclic antidepressant] is [gastric lavage better than charcoal or nothing] at [reducing toxicity]?

\section{Search strategy}

Medline 1966-10/02 using the Ovid interface. [(exp gastric lavage OR gastric lavage.mp OR washout.mp OR exp irrigation or lavage.mp OR gastric emptying.mp) AND (exp disipramine OR exp antidepressive agents, tricyclic OR exp antidepressive agents OR exp amitriptyline OR exp imipramine OR tricyc\$.mp OR amitriptyline.mp) AND (exp poisoning OR poisoning.mp OR exp overdose OR overdose.mp)] LIMIT to human AND English Language.

\section{Search outcome}

Altogether 82 papers found, 81 of which were not relevant to the question. The remaining paper is shown in table 4 .

\section{Comment(s)}

This study shows no statistically significant difference between the three groups. Although it seems small it has $80 \%$ power for showing a change of ITU admission time of 12 hours at $\mathrm{p}=0.05$. Furthermore, a study by Watson et al showed that only $8.7 \%$ (95\% C.I. 0.4 to $21.7 \%$ ) of the estimated dose of tricyclic was recovered by gastric lavage.

\section{- CLINICAL BOTTOM LINE}

There is no evidence for gastric lavage in tricyclic antidepressant overdose.

Bosse GM, Barefoot JA, Pfeifer MP, et al. Comparison of three methods of gut decontamination in tricyclic antidepressant overdose. J Emerg Med 1995:13:203-9.

Watson WA, Leighton H, Guy J, et al. Recovery of cyclic depressants with gastric lavage. J Emerg Med 1989;7:373-7.

\begin{tabular}{|c|c|c|c|c|c|}
\hline $\begin{array}{l}\text { Author, date } \\
\text { and country }\end{array}$ & Patient group & $\begin{array}{l}\text { Study type } \\
\text { (level of } \\
\text { evidence) }\end{array}$ & Outcomes & Key results & Study weaknesses \\
\hline \multirow{5}{*}{$\begin{array}{l}\text { Bosse GM et } \\
\text { al, 1995, USA }\end{array}$} & \multirow{2}{*}{$\begin{array}{l}51 \text { patients presenting with tricyclic } \\
\text { overdose. }\end{array}$} & \multirow[t]{5}{*}{ RCT } & \multirow[t]{2}{*}{ Mean length of stay } & \multirow{5}{*}{$\begin{array}{l}93.3(+/-94.3) \text { hours } v 107.2 \\
(+/-106.8) \text { hours } \vee 66.7(+/- \\
41.7) \text { hours }(\mathrm{p}=0.473) \\
66.9(+/-96.0) \text { hours } v 54.1 \\
(+/-34.3) \text { hours } v 34.4(+/- \\
27.3) \text { hours }(\mathrm{p}=0.436) \\
43.4(+/-17.7) \text { hours } v 24.1 \\
(+/-18.3) \text { hours } v 17.8(+/- \\
14.0) \text { hrs }(\mathrm{p}=0.321) \\
2 / 22 \vee 3 / 14 \vee 3 / 15(\mathrm{p}=0.501)\end{array}$} & Not blinded \\
\hline & & & & & Small numbers \\
\hline & $\begin{array}{l}\text { Charcoal only }(n=22) v \text { charcoal } \\
\text { then lavage }(n=14) \vee \text { charcoal then } \\
\text { lavage then charcoal }(n=15)\end{array}$ & & Mean length ICU stay & & \multirow{3}{*}{$\begin{array}{l}\text { Variations between } \\
\text { presenting GCS and } \\
\text { drug levels between } \\
\text { groups } \\
\end{array}$} \\
\hline & 39 intubated & & $\begin{array}{l}\text { Mean mechanical } \\
\text { ventilation time }\end{array}$ & & \\
\hline & & & Aspiration & & \\
\hline
\end{tabular}




\section{Treatment of uncomplicated subungual haematoma}

\section{Report by Nicola Batrick, Specialist Registrar Checked by Kambiz Hashemi and Ramzi Freii, Consultants \\ Abstract}

A short cut review was carried out to establish whether nail removal and nail bed repair is better than simple trephining in patients with significant subungual haematoma. Altogether 312 papers were found using the reported search, of which four presented the best evidence to answer the clinical question. The author, date and country of publication, patient group studied, study type, relevant outcomes, results and study weaknesses of these best papers are tabulated. A clinical bottom line is stated.

\section{Clinical scenario}

A patient attends the emergency department having sustained a crush injury to the tip of their right index finger. This has resulted in a painful subungual haematoma but no other significant fingertip injury.

\section{Three part question}

In [a patient presenting with a sizeable uncomplicated subungual haematoma] is [removing the nail and repairing the nail bed laceration better than simple trephining] at [providing the best cosmetic and functional result]?

\section{Search strategy}

Medline 1966-10/02 using the OVID interface. [subungual hematoma.mp OR nail bed laceration.mp OR nail bed injuries.mp OR exp NAILS/su] LIMIT to human AND English.

\section{Search outcome}

Altogether 312 papers were identified of which 308 were considered to be irrelevant or of insufficient quality for inclusion. The other four papers are shown in table 5 .

\section{Comment(s)}

It has been suggested that for subungual haematomas greater than $50 \%$ of the nail bed, the nail should be removed and the associated nail bed laceration repaired to ensure optimal cosmetic and functional results. However, there are insufficient clinical studies comparing treatment modalities to support this. It seems from the studies quoted that simple trephining of the nail in an uncomplicated subungual haematoma with no other significant finger tip injury gives good cosmetic and functional results.

\section{- CLINICAL BOTTOM LINE}

In both adults and children with a subungual haematoma with no other significant finger tip injury, treatment by trephining gives a good cosmetic and functional result.

Simon RR, Wolgin M. Subungual hematoma: Association with laceration requiring repair. Am J Emerg Med 1987;5:302-4.

Seaberg DC, Angelos WJ, Paris PM. Treatment of subungual hematomas with nail trephination: A prospective study. Am J Emerg Med 1991;9:209-10.

Meek S, White $M$. Subungual haematomas: is simple trephining enough? J Accid Emerg Med 1998;15:269-71.

Roser SE, Gellman H. Comparison of nail bed repair versus nail trephination for subungual hematomas in children. J Hand Surg [Am] 1999;24:1 166-70.

\begin{tabular}{|c|c|c|c|c|c|}
\hline $\begin{array}{l}\text { Author, date } \\
\text { and country }\end{array}$ & Patient group & $\begin{array}{l}\text { Study type } \\
\text { (level of } \\
\text { evidence) }\end{array}$ & Outcomes & Key results & Study weaknesses \\
\hline $\begin{array}{l}\text { Simon RR and } \\
\text { Wolgin M, } \\
\text { 1987, USA }\end{array}$ & $\begin{array}{l}47 \text { consecutive patients presenting to an } \\
\text { emergency department with subungual } \\
\text { haematoma }>25 \% \text { nail bed. }+/ \text { - fracture of } \\
\text { distal phalanx } \\
\text { Digital block, nail removed and lacerations } \\
\text { of nail bed greater than } 2-3 \mathrm{~mm} \text { repaired } \\
\text { using vicryl and nail replaced }\end{array}$ & $\begin{array}{l}\text { Prospective } \\
\text { observational } \\
\text { study }\end{array}$ & $\begin{array}{l}\text { Association of } \\
\text { SUH size and } \\
\text { repairable } \\
\text { laceration. }\end{array}$ & $\begin{array}{l}16 / 27 \text { patients with haematoma } \\
>50 \% \text { had nail bed laceration } \\
\text { requiring repair }\end{array}$ & $\begin{array}{l}\text { Often quoted paper } \\
\text { but no follow up of } \\
\text { patients and no } \\
\text { control group }\end{array}$ \\
\hline $\begin{array}{l}\text { Seaberg DC ef } \\
\text { al, 1991, USA }\end{array}$ & $\begin{array}{l}48 \text { patients presenting to an emergency } \\
\text { department with subungual haematoma } \\
\text { Nail and nail margin intact. }+ \text { /- distal } \\
\text { phalanx fracture } \\
\text { Electrocautery nail trephination } \\
\text { Follow up at least } 6 / 12\end{array}$ & $\begin{array}{l}\text { Prospective } \\
\text { observational } \\
\text { study }\end{array}$ & $\begin{array}{l}\text { Pain relief, } \\
\text { infection and } \\
\text { cosmetic } \\
\text { appearance }\end{array}$ & $\begin{array}{l}94 \% \text { follow up. All reported a } \\
\text { reduction in pain. No infective } \\
\text { complications or major nail } \\
\text { deformities regardless of SUH size } \\
\text { or fracture }\end{array}$ & $\begin{array}{l}\text { Major nail } \\
\text { deformities not } \\
\text { clearly defined } \\
\text { No control group }\end{array}$ \\
\hline $\begin{array}{l}\text { Meeks S and } \\
\text { White M, } \\
\text { 1997, UK }\end{array}$ & $\begin{array}{l}123 \text { patients presenting to emergency } \\
\text { departments treated by simple trephining } \\
94 \text { followed up for } 5-13 \text { months }\end{array}$ & Retrospective & $\begin{array}{l}\text { Functional and } \\
\text { cosmetic } \\
\text { appearances }\end{array}$ & $\begin{array}{l}\text { Excellent ie no residual } \\
\text { abnormality or very good in } 85 \% \\
\text { of those followed up. } \\
2 \% \text { poor outcome caused by nail } \\
\text { splitting. Major nail abnormality } \\
\text { defined by Zook's criteria occurred } \\
\text { in } 11 \% \\
\text { Infection in } 5 \text { patients. No } \\
\text { correlation between adverse } \\
\text { outcome and haematoma size, } \\
\text { presence of fracture or infection }\end{array}$ & $\begin{array}{l}\text { Retrospective } \\
\text { Coding inadequate } \\
\text { No control group } \\
\text { Loss of patients to FU }\end{array}$ \\
\hline $\begin{array}{l}\text { Roser SE and } \\
\text { Gellman H, } \\
\text { 1999, USA }\end{array}$ & $\begin{array}{l}53 \text { finger injuries in children with intact nail } \\
\text { and nail margin, }+/- \text { tuft fracture. } \\
\text { Formal nail bed repair } v \text { simple trephining/ } \\
\text { conservative. } \\
\text { FU at least } 4 / 12\end{array}$ & $\begin{array}{l}\text { Sequential } \\
\text { study }\end{array}$ & $\begin{array}{l}\text { Cosmetic } \\
\text { deformity of nail } \\
\text { and functional } \\
\text { deficit } \\
\text { Infective } \\
\text { complications } \\
\text { Costs }\end{array}$ & $\begin{array}{l}\text { No infective complications in either } \\
\text { group } \\
\text { Costs significantly higher in } \\
\text { operative group }\end{array}$ & No randomisation \\
\hline
\end{tabular}




\section{Use of sterile gloves in the treatment of simple wounds}

\section{Report by Derek Keith Sage, East Anglian} Trainees

\section{Checked by Jon Argall, Senior Clinical Fellow} Abstract

A short cut review was carried out to establish whether the use of sterile gloves during the treatment of simple wounds reduces infections. Altogether 48 papers were found using the reported search, but none presented any evidence to answer the clinical question. More research is needed in this area and, in the mean time, local advice should be followed.

\section{Clinical scenario}

A patient presents to the emergency department with a laceration to his left hand. The wound needs cleaning and suturing. You wonder whether sterile gloves are really necessary in the treatment of simple wounds.

\section{Three part question}

In [patients with simple wounds] does the use of [sterile gloves rather than clean non-sterile gloves] produce less [wound infections]?

\section{Search strategy}

Medline 1966-10/02 using the OVID interface. [exp "wounds and injuries" OR exp wounds, penetrating OR exp lacerations OR laceration.mp] AND [exp gloves, surgical OR exp gloves, protective OR glove.mp] AND [exp infection OR infection.mp OR exp focal infection OR exp surgical wound infection OR exp wound infection] LIMIT to human AND English.

\section{Search outcome}

Altogether 48 papers were found none of which directly answered the question.

\section{Comment(s)}

There seems to be no available evidence for the use of sterile gloves over clean non-sterile gloves in the treatment of simple traumatic wounds.

\section{- CLINICAL BOTTOM LINE}

It is arguably unethical to start using non-sterile gloves where the tradition has been to use sterile gloves but this is an area for potential research.

\section{Antibiotics in orbital floor fractures}

\section{Report by Bruce Martin, Specialist Registrar Checked by Angaj Ghosh, Senior Clinical Fellow Abstract}

A short cut review was carried out to establish whether prophylactic antibiotics are indicated in patients with undisplaced maxillary or orbital floor fractures. Altogether 214 papers were found using the reported search, but none presented any evidence to answer the clinical question. More research is needed in this area and, in the mean time, local advice should be followed.

\section{Clinical scenario}

A 28 year old man presents to the emergency department with a punch injury to the left side of his face after a fracas. Clinical examination reveals no wound, but tenderness, bruising and swelling over the left infraorbital area. Radiological examination confirms the presence of fluid within the maxillary sinus, suggesting an undisplaced fracture of the orbital floor. You wonder whether you should prescribe him oral antibiotics to reduce the incidence of infection.

\section{Three part question}

In [patients with undisplaced maxillary or orbital floor fractures] are [antibiotics better than no antibiotics] at [preventing infective complications]?

\section{Search strategy}

Medline 1966-10/02 using the OVID interface. [(exp facial bones OR exp facial injuries OR facial.mp) AND (exp fractures OR exp maxillary fractures OR exp orbital fractures OR exp zygomatic fractures OR fracture\$.mp) AND (exp antibiotics OR antibiotic\$.mp)] LIMIT to human AND English.

\section{Search outcome}

Altogether 214 papers were found of which all were of irrelevant or of insufficient quality.

\section{Comment(s)}

The evidence in this field is clearly lacking. There are no trials of any kind looking at the incidence of infection in patients with undisplaced orbital floor fractures. There is clearly a need for further investigation into this area.

- CLINICAL BOTTOM LINE

Local advice should be followed.

\section{Contraindications to thrombolysis in patients taking coumarins}

\section{Report by Andy Ashton, Senior Clinical Fellow Checked by Stewart Teece, Clinical Research Fellow}

Abstract

A short cut review was carried out to establish what level of INR was a contraindication to thrombolysis in patients taking warfarins. Altogether 296 papers were found using the reported search, but none presented any evidence to answer the clinical question. More research is needed in this area and, in the mean time, local advice should be followed.

\section{Clinical scenario}

A 73 year old woman presents to the emergency department with chest pain. Her ECG shows left bundle branch block. She is taking warfarin for recurrent pulmonary emboli. Her INR is 2.7. While you look for her old notes to see if her left bundle branch block is new or not, you try to find out at what INR thrombolysis is contraindicated. Everyone gives you an answer, but the answers are all different. You wonder if there is any evidence to support any of the recommendations.

\section{Three part question}

In [a patient with myocardial infarction who is anticoagulated] at what [INR] is [thrombolysis contraindicated]?

\section{Search strategy}

Medline 1966-10/02 using the OVID interface. [exp urinary plasminogen activator OR exp thrombolytic therapy OR exp fibrinolysis OR exp tissue plasminogen activator OR exp fibrinolytic agents OR exp streptokinase OR thromboly\$.af OR streptokinase.af OR urokinase.af OR TPA.af OR (tissue adj5 
plasminogen adj5 activator).af OR fibrinoly\$.af OR plasminogen activator.af] AND [exp International Normalized Ratio OR INR.af OR exp warfarin OR cumarin.af OR (International adj5 normalized adj5 ratio).af OR (International adj5 normalised adj5 ratio).af OR coumarin.af OR BSR.af OR (British adj 5 standardised adj5 ratio).af OR (Brtitish adj5 standardized adj5 ratio).af OR prothrombin.af ] AND [exp myocardial infarction OR (myocard\$ adj5 infarct\$).af OR (heart adj5 attack).af OR stenocardia.af] LIMIT to human AND English.

\section{Search outcome}

Altogether 96 papers were found none of which were relevant to the three part question.

\section{Comment(s)}

Although various guidelines exist for thrombolysis in a patient who is anticoagulated, there does not seem to be any research evidence base for this.

\section{- CLINICAL BOTTOM LINE}

Local advice should be followed. 